\title{
The Many Faced Masculinities in A Game of Thrones
}

\author{
Game of Thrones'da Çok Yüzlü Erkeklik Türleri
}

\section{Cenk TAN *}

\begin{abstract}
A Game of Thrones is a stunning medieval fantasy which tells the story of the immense struggle for power in an ancient world named 'The Seven Kingdoms'. It was originally written as a series of novels by the American author George R. R. Martin in 1996 and adapted to the TV screen by HBO in 2011. The series has completed its sixth season and is scheduled to go on for a total of eight seasons. Since its first broadcast in 2011, A Game of Thrones has attracted millions of viewers on a global scale and has received a total of 38 Emmy Awards. In A Game of Thrones, gender is one of the central themes, as power relations generally evolve around different gender roles. This study analyses masculinity in $A$ Game of Thrones and the different types of masculinities which are identified through various male and female characters. This classification places all of the characters in two distinct gender categories. It also reveals the impact of these diverse forms of masculinities on the lives of the main characters and the general storyline of the production. Thus, the paper deconstructs the constructed masculinities in A Game of Thrones by exposing their representation through the main characters.
\end{abstract}

Keywords: A Game of Thrones, Masculinity, Raewyn Connell, Gender Roles, Cultural Studies

Öz: A Game of Thrones, Yedi Krallık olarak adlandırılan antik bir dünyada iktidar mücadelesini anlatan eşsiz bir fantastik ortaçağ hikâyesidir. İlk kez 1996'da Amerikalı yazar George R. R. Martin tarafindan roman serisi olarak yazılan eser, HBO şirketi tarafindan 2011 yılında televizyona uyarlanmıştır. Altıncı sezonunu bitiren dizinin sekiz sezonda tamamlanacağı duyurulmuştur. 2011'deki ilk yayımlanışından beri milyonlarca izleyiciyi kendine bağlayan dizi toplamda 38 Emmy ödülüne layık görülmüsstür. A Game of Thrones'ta cinsiyet ana temalardan biridir, çünkü iktidar mücadeleleri çeşitli cinsiyet rollerinin etrafinda sürdürülmektedir. Bu makale A Game of Thrones'ta erkeklik kavramını ve karakterlerde gözlenen çeşitli erkeklik modellerini analiz etmektedir. Sınıflandırma tüm karakterleri iki farklı cinsiyet kategorisine göre konumlandırmaktadır. Bu erkeklik tasvirlerinin, karakterlerin gelişimine ve kurgunun genel seyrine etkisini de mercek altında almaktadır. Böylece ana karakterlerde temsil bulan erkeklik türlerinin yapı sökümüne uğratılarak, gerçek kimliklerinin açığa çıkarılması hedeflenmektedir.

Anahtar sözcükler: Game of Thrones, Erkeklik, Raewyn Connell, Cinsiyet Rolleri, Kültürel İncelemeler

A Game of Thrones is a stunning medieval fantasy which tells the story of the immense struggle for power in an ancient location named 'the Seven Kingdoms'. It was originally written as a series of novels by the American author George R. R. Martin in 1996 and adapted to the TV screen by HBO in 2011. The series has completed its sixth season and is scheduled to go on for a total of eight seasons. Since its first broadcast in 2011, A Game of Thrones has attracted millions of viewers on a global scale and has received a total of 38 Emmy Awards.

The main plot of the series is founded on A Song of Ice and Fire and takes place in the imaginary continents Westeros and Essos. It tells the struggle for the 'Iron Throne' between the

\footnotetext{
* Lecturer, Pamukkale University, School of Foreign Languages, Denizli. ctan@pau.edu.tr
} 
houses of Westeros: House Stark of Winterfell, House Lannister of Casterly Rock, House Baratheon of Storm's End, House Tully of Riverrun, House Arryn of the Eyrie, House Tyrell of Highgarden and House Martell of Sunspear. These are the names of the seven great houses which are predominantly influential. Besides these, there is also House Greyjoy of Pyke and House Targaryen of King's Landing. The Targaryens used to be the powerful dynasty which ruled the Seven Kingdoms for as long as 280 years. King Aegon I conquered all the six independent kingdoms with the help of his three dragons and united all of Westeros and Essos. After three centuries of Targaryen reign, King Aerys II was overthrown by Robert of House Baratheon and his many followers. After Robert Baratheon sits on the Iron Throne, he rules the Realm for seventeen years. Robert tragically dies after getting severely wounded in a hunting party. Together with Robert Baratheon's death, the struggle between the many houses of Westeros for the iron throne finally begins.

This study analyses masculinity in A Game of Thrones and the many types of masculinities which are identified through various male and female characters. It also reveals the effects of these different forms of masculinities on the lives of the main characters and the general storyline of the series. Thus, the paper deconstructs the constructed masculinities in A Game of Thrones. Gender is one of the central issues in A Game of Thrones as power relations generally evolve around different gender identities. The Medieval age setting imposes a strictly hierarchal and patriarchal structure on the people. On top of the structure, there is the king, below him the wardens and then the lords followed by the common people at the lowest bottom. So, it is not surprising that in A Game of Thrones, men are kings, warriors, lords, sirs, guardians, priests etc. whereas women are ladies, slaves, whores, servants, possessions etc. A Game of Thrones depicts a seriously sexist world where women exist for the sake of their sexuality. It reflects a primitive world of battles and masculine fights with men swinging swords at each other to prove their masculinity. There are lots of characters in A Game of Thrones and it is practically impossible to analyse all of them. However, I shall place the characters in two distinct 'gender' categories: a) mainstream (heteronormative) characters and b) non-traditional (non-conformist) characters.

First and foremost, it is vital to comprehend and analyse the notions of men and masculinity. Masculinity is a social construct which comes in many types and various representations. It is subject to power relations and ideology. Harry Brod and Michael Kaufman $(1998,104)$ argue that;
"In comparison, masculinities exist and persist as ideology, often in their surface form in terms of elements of production and reproduction (Hearn, 1987, p. 98). Particular masculinities are not fixed formulas but rather they are combinations of actions and signs, part powerful, part arbitrary, performed in reaction and relation to complex material relations and emotional demands; these signify that this is man. Masculinities are thus ideological signs of particular men of the gender class of men, particularly in relation to reproduction broadly defined".

Hence, it is obvious that masculinity is defined by our choices and actions. It is not who we are but what we do and what we choose which defines our identity as being men. This is also the case in A Game of Thrones as the masculinity of the characters is largely defined by men's actions and the choices they make. Prominent characters such as Ned, Robb, Bran and Arya Stark, Tywin, Tyrion Jamie and Cersei Lannister are all crucial figures whose actions define their final outcome. French sociologist Pierre Bourdieu $(2007,9)$ confirms this and adds that:

"It is the concordance between the objective structures and the cognitive structures, between the shape of being and the forms of knowledge, between the course of the world and expectations about it, that makes 
possible what Husserl described under the name of the 'natural attitude' or 'doxic experience' -but without pointing to its social conditions of possibility. This experience apprehends the social world and its arbitrary divisions, starting with the socially constructed division between the sexes, as natural, self-evident, and as such contains a full recognition of legitimacy. It is because they fail to observe the action of deep-rooted mechanisms, such as those which underlie the agreement between cognitive structures and social structures, and consequently the doxic experience of the social world".

As Bourdieu states, there is always a difference between the objective structure and the cognitive structure. (9) This emphasizes the notion that masculinity is a social construct. Our objective structure is the biological body we possess, whereas the cognitive structure is the socially constructed identity which creates a certain separation between the sexes as Bourdieu points out.

Australian sociologist and scholar Raewyn Connell contributed greatly to the theory of masculinity by defining and categorizing several different types of masculinity. Connell identified four categories of masculinity: hegemonic, complicit, subordinate and marginalized. She derived the term 'hegemonic' from Antonio Gramsci's notion of hegemony. (Connell 1995, 77) Hegemonic masculinity is the dominant form of masculinity which is anticipated and encouraged by patriarchal society. Connell points out that hegemonic masculinity is the source of our present-day conflicts and ensures the hegemony of men while confirming the subordination of women. (77)

Connell $(1995,77)$ maintains that:

Hegemonic masculinity can be defined as the configuration of gender practice which embodies the currently accepted answer to the problem of the legitimacy of patriarchy, which guarantees (or is taken to guarantee) the dominant position of men and the subordination of women".

Nonetheless, the general notion of masculinities has faced much criticism and opposition. The concept was claimed to be vague, unclear in meaning and unnecessary to comprehend power relations of men. (Connell \& Messerschmidt 2005, 836) In addition, the multiple masculinities categorisation is said to constitute a static typology. (836) In the article published in 2005, Connell and Messerschmidt responded to these criticisms by asserting that masculinities stands away from essentialism and homogeneity due to the various social constructs that ethnographers have retained with the help of masculinities. Masculinities also refrain from essentialism mainly because it can simultaneously be applied to humans with female bodies. (836) Masculinity rejects being a stable theory confined to a person's body or character qualities. As it is pointed out by Connell and Messerschmidt, masculinities are not only confined to men and men's relationships but focus rather on relational interconnectedness within gender boundaries. (837)

Hegemonic masculinity is regarded as the mainstream form of dominant masculinity that is encouraged and exemplified by patriarchal society. A Game of Thrones possesses various hegemonic male characters. The common quality of these figures is that they stand at the top of the hierarchal chain. Hegemonic masculinity is embodied within the most powerful male characters of A Game of Thrones; Robert and Stannis Baratheon, Ned Stark and Tywin Lannister are the three main hegemonic figures who are the subject of my analysis. All of these characters are mainstream, heterosexual white males.

Robert Baratheon is the King of Westeros until his death. He rules the country in alliance 
with House Stark and other families. Robert's reign lasts for seventeen years. He has every single characteristic that a King has: he is tough, macho, masculine, physically strong and combative. A dialogue between Robert and Jamie Lannister reveals certain notions regarding his hegemonic masculinity:

\author{
"Robert Baratheon: We're telling war stories. Who was your first kill, \\ not counting old men? \\ Jaime Lannister: One of the outlaws in the Brotherhood. \\ Barristan Selmy: [to Jaime] I was there that way. You were only a \\ squire, sixteen years old. \\ Jaime Lannister: [to Selmy] You killed Simon Toyne with a counter \\ riposte. Best move I ever saw. \\ Barristan Selmy: Good fighter, Toyne, but he lacked stamina. \\ Robert Baratheon: Your outlaw... any last words? \\ Jaime Lannister: I cut his head off, so... no. \\ Robert Baratheon: What about Aerys Targaryen? What did the Mad \\ King say when you stabbed him in the back? I never asked. Did he call \\ you a traitor? Did he plead for a reprieve? \\ Jaime Lannister: He said the same thing he had been saying for hours... \\ "burn them all". [Robert gapes at Jaime] \\ Jaime Lannister: If that's all, your Grace...” (Benioff \& Weiss) (S.1E.3)
}

For Robert, being a man is about being strong and eventually being a killer. This conversation is a very masculine dialogue where both men share anecdotes concerning their 'first kill' and as Robert says: 'old men don't count as kills.' (S.1E.3) Robert is the ultimate patriarch of Westeros until his death. As the King of Westeros, he embraces violence and killing, just like any other male character in A Game of Thrones.

A second example of hegemonic masculinity in the series is King Robert's hand, Eddard (Ned) Stark who also happens to be the warden of the North. Ned Stark is considered to be King Robert's hand and best friend. He is a highly reliable lord of the North who is deeply respected by everyone throughout the country. King Robert also relies on him to make his major decisions and counts on his professional advice. Ned is an indispensable ally of King Robert and many other characters who are close to the King envy their friendship and mutual respect. During the first episode of season one, a dialogue between Ned and his paralyzed son Bran draws our attention:

"[after Will's execution]

Eddard Stark: You understand why I did it?

Bran Stark: Jon said he was a deserter.

Eddard Stark: But do you understand why I had to kill him?

Bran Stark: Our way is the old way?

Eddard Stark: The man who passes the sentence should swing the

sword.

Bran Stark: Is it true he saw the White Walkers?

Eddard Stark: The White Walkers have been gone for thousands of

years.

Bran Stark: So he was lying.

Eddard Stark: A madman sees what he sees".

(Benioff \& Weiss) (S.1E.1) 
Ned utters these lines right after he decapitates a man who has been proven to be a deserter. He is trying to mentor his disabled little boy, Bran. Ned highlights the significance of implementing what a lord and hand of the King is supposed to do at times like these. For a powerful lord like Ned, passing a sentence and swinging a sword to take a man's life is only a matter of seconds. By doing that, he empowers his masculinity and teaches his own son who is born with a disability and lacks masculinity by birth. Eddard Stark is the embodiment of the fact that hegemonic masculinity also comprises positive qualities. As discussed by Jacoby (2012, 89-90):

"Eddard also is courageous, just, and honorable, which makes him a pretty virtuous guy. Being virtuous and acting accordingly may come at a price. Eddard's frankness results in his imprisonment. His honesty makes him blind to other people's deceit. (...) On the one hand, Eddard is bound by honesty and cannot bend the knee to Joffrey and accept him as king; on the other hand, he loves his daughters dearly and must not forsake them. He eventually bends the knee to Joffrey and confesses his "treason" so his daughters can be safe".

Eddard's blind honesty eventually causes his downfall. His being too virtuous and acting accordingly leads him to make a choice between himself and his family. As it is expected from him, he confesses so that his children and family can remain safe. Eddard Stark sacrifices himself in order to save his family.

Other hegemonic male characters are Stannis Baratheon, King Robert's brother who claims the throne after his death and revolts against the Lannisters but gets emasculated after losing the battle of Blackwater. Tywin Lannister, the patriarch of the wealthy Lannister family who is also the father of Cersei, Robert's wife, is another prominent character who conforms to hegemonic masculinity.

However, Raewyn Connell's concept of hegemonic masculinity has met serious opposition during the last decade. The major criticism towards the concept is that the hegemonic state and practices are ambiguous. (Connell \& Messerschmidt 2005, 838) Connell responds that ambiguity itself is a necessity for gender practices. There appear to be certain praised models of masculine behaviour which we are exposed to. However, these models do not comply with the common realities of daily life. (838) Thus, hegemonic masculinities may not always be compatible with the actual lives of men. Connell $(2005,839)$ argues that:

\begin{abstract}
"At the local level, hegemonic patterns of masculinity are embedded in specific social environments, such as formal organizations. Hegemonic patterns of masculinity are both engaged with and contested as children grow up. Gender is made in schools and neighborhoods through peer group structure, control of school space, dating patterns, homophobic speech, and harassment.(...) In none of these cases would we expect hegemonic masculinity to stand out as a sharply defined pattern separate from all others. A degree of overlap or blurring between hegemonic and complicit masculinities is extremely likely if hegemony is effective".
\end{abstract}

This kind of overlapping and transition between hegemonic and complicit masculinities is also visible in A Game of Thrones. Some of the characters do not conform to any fixed type of masculinity but experience transitions from one to the other. To give a specific example, Ned Stark begins his quest as a hegemonic family patriarch but later passes over into a state of complicit masculinity due to a major injury and finally gets executed. Ned is not the only character who experiences transition. There are many other figures whose gender roles overlap 
in time. Daenerys Targaryen is introduced as a weak woman figure at the beginning of the series. As she accumulates power by marrying Khal Drogo, Khaleesi collects an army and step by step delves into a state of hypermasculinity.

However, it is worth noting that this study takes the commonly acknowledged categorization of the characters into account. Khaleesi's weak condition lasts for a short period and soon afterwards she transforms into the almighty queen which we are more familiar with. Daenerys exhibits hypermasculine qualities as soon as she starts raising an army of her own. The same counts for other characters as well. There are certain periods when characters experience transition from one type of masculinity to the other. This however does not change each character's dominant form of masculinity. Jamie Lannister, son of the powerful patriarch Tywin Lannister, emerges as a hegemonic character at first. As the series progresses, Jamie first loses his father and then his hand, which results in an ultimate loss of power. Jamie's character shifts from hegemonic to complicit masculinity.

Another criticism to hegemonic masculinity is that it strongly reifies men's behaviour and acts as a justification for that particular behaviour $(2005,840)$. Due to the fact that hegemonic behaviour permits men to continue with their violent actions, it forms a justification for domination, especially over women. Nevertheless, violence, selfishness and hostility are not the only characteristics of hegemonic masculinity. This notion also includes positive qualities which are overlooked by many critics. Fatherhood, being a breadwinner and a stable partner are some of those features that need to be kept in mind. In A Game of Thrones, characters which comply with hegemonic masculinity also clearly manifest positive traits.

Tywin Lannister, one of the ultimate patriarchs in the series is a perfect example of hegemonic masculinity. Tywin's actions are motivated by an ambition to protect the house and its family name for the many generations to come. An insanely rich lord, he does everything to come to power and later to stay in power. As he assembles one of the greatest armies in Westeros, he falls out with his dwarf son, Tyrion which eventually leads to his ultimate ruination. As mentioned earlier, Eddard Stark is another character who represents hegemonic masculinity and embodies certain positive characteristics.

In a book published recently, James W. Messerschmidt $(2018,60)$ paid a tremendous effort in reformulating the concept of hegemonic masculinity:

"Empirically existing hegemonic masculinities exist at local, regional, and global levels; hegemonic masculinities are formed through an unequal and hierarchical relationship between masculinities and femininities (even though femininities may be constructed in and through male bodies); and through this relationship hegemonic masculinities circulate a legitimating justification for unequal gender relations".

Messerschmidt's reformulation of the notion indicates that masculinities exist not just in relation to other masculinities but also in relation to femininities. Hegemonic masculinities not only exert pressure on other men but also on other constructs of gender including women and queers. He also adds there are different types of masculinities at a variety of scales, ranging from the local to the international and global. However, all these form the basis for rationalization of unbalanced gender relations as these relationships in essence are hierarchical. (60)

In addition, there are also characters which comply with subordinate masculinity. Raewyn Connell $(1995,78)$ defines the concept as:

"The most important case in contemporary European/American society 
is the dominance of heterosexual men and the subordination of homosexual men. This is much more than a cultural stigmatization of homosexuality and gay identity. Gay men are subordinated to straight men by an array of quite material practices".

Subordinate masculinity is commonly identified with homosexuality and tendencies that adhere to the LGBT movement. These tendencies belong to the non-traditional characters group in the categorization which I have stated earlier and possess a prominent role in the series. At the other side of hegemonic masculinity stands subordinate masculinity. The reason why people are considered subordinate is mainly due to the fact that they do not conform to mainstream heterosexual norms of the society. These people usually manifest other types of sexual preferences and are subordinated by the dominant, hegemonic group.

There are many queer characters in A Game of Thrones. As a matter of fact, this is one of the reasons why the series has been under constant criticism and attack by the mainstream media. Queer theory is explained as:

"Not a singular or systematic conceptual or methodological framework, but a collection of intellectual engagements with the relations between sex, gender and sexual desire. If queer theory is a school of thought, then it's one with a highly unorthodox view of discipline. The term describes a diverse range of critical practices and priorities: readings of the representation of same-sex desire in literary texts, films, music, images; analyses of the social and political power relations of sexuality; critiques of the sex-gender system; studies of transsexual and transgender identification, of sadomasochism and of transgressive desires" (Spargo 2009, 9).

Hence, the notion of queerness has grown to become a literary theory which focuses on gender and sexual relations. It is applied to a wide variety of areas from literature to media and popular culture. The basic queer characters in A Game of Thrones are Renly Baratheon, Loras Tyrell, Oberyn Martell, Ellaria Sand, Lady Brienne of Tarth, Yara Greyjoy and Lord Varys. The most commonly known representation of a homosexual relationship in A Game of Thrones is that between Renly Baratheon and Sir Loras Tyrell. Renly Baratheon is the youngest sibling of former king Robert Baratheon and Stannis Baratheon. He marries Margaery, a noble woman from house Tyrell but actually has a sexual and emotional relationship with his wife's brother, Loras Tyrell. Later, Renly gets killed in his tent by a shadow creature that looks like Stannis. Renly's homosexual relationship with Loras Tyrell is openly revealed through several sex scenes. In season six, Loras Tyrell gets caught and sentenced by the High Septon and the militants of the Faith. During his trial, Loras Tyrell openly confesses his sins:

"To which crimes will you be confessing? All of them. I lay with other men including the traitor Renly Baratheon. (crowd murmuring louder) I perjured myself before the gods. I am guilty of depravity... dishonesty, profligacy, and arrogance. I see that now. I humble myself before the Seven and accept whatever punishment the gods deem just. I take full responsibility for my many sins and unburden myself of my desires" (Benioff \& Weiss) (S.6E.10).

It seems that any form of queer activity, though common around the country, seems to be shunned, despised and widely regarded as sin. In this monologue, Loras Tyrell confesses his guilt and proclaims to everyone that he is gay. Besides these queer characters, there is also 
Oberyn Martell, the Prince of Dorne who openly reveals a bisexual identity. Oberyn is supposedly married to the beautiful Ellaria Sand with four children. Both Oberyn and Ellaria are known to be sexually promiscuous and attracted to both sexes.

One of the most controversial characters in A Game of Thrones is, no doubt, Yara Greyjoy. Yara is the Queen of the Iron Islands and elder sister to Theon Greyjoy. This is one of the serious discrepancies between the books and the TV series. In the books, the character is called Asha Greyjoy and according to author, George Martin is not lesbian at all. This is a huge deviation created by the producers of the series. In the series, Yara is depicted as an exhibitionist lesbian who does not miss the slightest chance to get her share of sexual action. Despite her lesbian depiction, Yara Greyjoy forms a typical example of toxic masculinity. Toxic masculinity is an aggressive, abusive and destructive form of hegemonic masculinity. The term is defined as:

"Those aspects of hegemonic masculinity that are socially destructive, such as misogyny, homophobia, greed, and violent domination; and those that are culturally accepted and valued" (Kupers 2001).

Hence, toxic masculinity is created from those aspects of hegemonic masculinity that are socially destructive. Indeed, Yara, despite being depicted as openly sexual displays all the characteristics of toxic masculinity. She was brought up by her father and although she is a woman, she seems to possess the qualities of the ultimate warrior. She is feminine on the outside but masculine to the heart. Yara abuses, destroys, rapes and dominates everyone who stands in her path. She even abuses her little brother, Theon and eventually deserts him with the ambition of assembling the biggest fleet of Westeros and joining forces with Khaleesi, Daenerys Targaryen. She is an unconventional type of lesbian who takes on men whenever she feels like it. She is a powerful, dominant woman who seems to enjoy defying men. Nicole M. Mares (2017, 153-154) defines Yara as:

\section{(...)"The most non-traditional, "lesbian-like" character in the Seven} Kingdoms. Yara is a pirate and a warrior. The first time we meet her, she is dressed as a woman but when we see Yara in subsequent scenes of Game of Thrones, she is rather androgynous and dressed in men's attire. It is clear that she is a strong woman, and her strength is magnified as Theon's own strength is diminished at the cruel hands of Ramsay Bolton. What women in the non-traditional, "lesbian-like" category show is that, while they may escape traditional gender and sex conventions for a time, their extraordinary accomplishments emphasize their gender and sex even more".

These non-traditional characters cannot seem to escape their own gender and sex no matter what action they take. In the eyes of the men of medieval society, they are regarded and looked down upon as mere women to be kept under strict control.

Another noteworthy character is Lady Brienne of Tarth. Lady Brienne is a gigantic, powerful and courageous female warrior who can take on the strongest knights. She is not only strong but also brave and committed to her cause. Lady Brienne is an obvious example of a Butch. Butches are generally regarded as lesbian women who claim and exhibit seriously masculine traits. They are commonly known to be biologically female but nevertheless share the looks and physical qualities of dominant men. They are unconventional women who do not comply with conventional female looks and behaviour.

According to Halberstam (2013, 95), the Butch lesbian is considered a failed type of lesbian: 
"What The $L$ Word must repudiate in order to represent lesbian as successful is the butch. The butch therefore gets cast as anachronistic, as the failure of femininity, as an earlier, melancholic model of queerness that has now been updated and transformed into desirable womanhood, desirable, that is, in a hetero- visual model. But the butch lesbian is a failure not only in contemporary queer renderings of desire; she stands in for failure in consumer culture writ large because her masculinity becomes a block to heteronormative male desire".

Lady Brienne of Tarth goes through a long and difficult quest. She descended from the House of Tarth from the island Tarth on the Narrow Sea. She possesses an extremely tall and muscular physical appearance. An appearance that is quite unusual for a woman. When she was still young, she developed an interest in fighting and physical combat. She lost her mother at a very young age and her siblings as well. In season 2, Lady Brienne joined the forces of King Renly Baratheon who later allied with Lady Catelyn Stark. After witnessing the death of Renly Baratheon, Lady Brienne was given the mission to be a personal guard of Lady Stark. She escorts Lady Stark to Jamie Lannister. Lady Stark orders Brienne to kidnap Jamie Lannister from a camp and hand him over to King's Landing in return for her daughters' safety. On her way to King's Landing, Lady Brienne eliminates many threats and kills many men who stand in their way. After delivering Jamie, Lady Brienne and her helper Podrick head out to seek Sansa Stark, the eldest daughter of Lady Catelyn Stark and Ned Stark. She finds Sansa at the Bolton's Castle and frees her after a fierce negotiation.

Halberstam $(1998,112)$ goes further to analyse that:

"In some way, across very different historical locations, stone butchness has been understood as a dysfunctional rejection of womanhood by a self-hating subject who cannot bear her embodiment. Stoneness becomes the literalization of castration (rather than castration anxiety), and the stone butch has been characterized as more blocked, more lacking, and more rigid than all other sexual identities".

Lady Brienne's character is definitely a noteworthy for analysis. As a Butch female, she not only shares the powerful physical qualities of a warrior but she also shares the compassion, determination and reliability of a noble woman. On the other hand, she also seems to be uneasy with her femininity. That explains why she is so introverted and reticent. Hence, she is physically male but mentally female. The best thing about Lady Brienne of Tarth is that whenever she gets into a fight with men, she mostly prevails. As a matter of fact, she is the only female character who can defeat men in physical combat. Her relationship with Jamie Lannister is quite intriguing. When she is given the mission to escort Jamie, both characters despise each other but after spending some time together they develop a mutual trust for each other. In her dialogues, despite her strong posture, Lady Brienne constantly mocks the antagonist man and always reminds him that she is a woman:

"Jaime Lannister: I hope you're pleased. If you had armed me, they would never have taken us.

Brienne of Tarth: You were armed when we were taken.

Jaime Lannister: I was in chains if you recall. Our little match would have ended quite quick if my hands weren't bound.

Brienne of Tarth: All my life I've been hearing, "Jaime Lannister, what a brilliant swordsman." You were slower than I expected. And more 
predictable...

Jaime Lannister: I've been sitting in a muddy pen wrapped in chains for the past year.

Brienne of Tarth: And I'm a woman. I was still beating you.

Jaime Lannister: You were not beating me.

Brienne of Tarth: Maybe you were as good as people said... once. Or maybe people just love to overpraise a famous name"

(Benioff \& Weiss) (S.3E.3)

Lady Brienne's sexual orientation is not openly revealed in the series. She might as well be bisexual or lesbian. What we know for sure is that she is an honourable female knight who happens to be the most loyal and consistent personality of the series. She defies and rejects stereotypical gender roles and decides to follow her heart. She plays a crucial role in the series as she changes the course of events. As a gender-bender, she proves to be the utmost loyal character in the series. Lady Brienne plays a vital role in changing the course of events in $A$ Game of Thrones and it is likely that she will continue to do so in upcoming episodes. James Lowder $(2012,139)$ describes Lady Brienne as some type of a courageous social outcast:

"Because her actions fall consistently and fully outside the social norms, Brienne provides a stark lesson on how women who dare to take male power for their own are judged and treated not only in Westeros but in all conventionally patriarchal societies. She also remains a study in heartbreaking contradictions. She embraces the romantic ideals of her culture, both emotionally and through her actions, but is continually betrayed by the real world, simply because she cannot turn herself into the woman the Westerosi legends tell her she should be".

Indeed, Lady Brienne is a social outcast simply because she fails to conform to the norms of the society of Westeros. These norms impose that women should be appealing, submissive and eternally obedient to their men. They should be the perfect partner, forever in service to their husband. Lady Brienne fails to meet all of these requirements. Not only is she awkward and non-conformist by nature, but also tremendously incompatible with the traditional female model. Her story is one of hope and survival.

Another prominent gender-bender character in A Game of Thrones is Arya Stark. Arya is the youngest of the two daughters of Ned Stark, former hand to ex-King Robert Baratheon. Arya is a young teenager girl who witnesses the brutal death of his father at the hands of the cruel King Joffrey. Later on, Arya's elder brother Robb and mother Catelyn Stark are brutally slaughtered during a feast held in their honour. Witnessing most of her close family getting murdered, Arya vows to take revenge on all those who are responsible for the killings. After the execution of her father, Ned Stark, Arya goes undercover by cutting her hair and assuming a male identity. This is so symbolical of her tomboy identity that the boyish girl becomes a tomboy. For years, Arya is forced to live with an undercover tomboy identity. She fully accepts this new identity as she sees it as a vital instrument of survival. Not only does she associate traditional girlhood with weakness and inferiority but also embraces the tomboy role as a beneficial means which will give her the opportunity to accomplish her goals. A dialogue between Tywin Lannister and the 'undercover' Arya Stark is a proof of Arya's opinions related to girlhood:

“Tywin Lannister: Hm. She's a heroine of yours, I take it. Aren't most girls more interested in the pretty maidens from the songs? Jonquil, with flowers in her hair? 
Arya Stark: Most girls are idiots.

Tywin Lannister: [laughs] You remind me of my daughter. Where did you learn all this stuff about Visenya and her Valyrian steel sword? Arya Stark: From my father" (Benioff \& Weiss) (S.2E.7).

After a long quest, Arya ends up in the free city of Braavos at the Faceless men, an assassin cult worshipping a deity they call "The Many Faced God". This is where Arya is prepared both mentally and physically to execute murder for revenge. Arya Stark is a typical tomboy character. She is a teenage girl with the looks and behaviour of a boy. The term tomboy is defined as:

"A girl who behaves like a spirited or boisterous boy; a wild romping girl; a hoyden" [...] Embedded within its reference to boisterous young women, the term fuses "notions of masculinity, promiscuous sexuality, prostitution, and lesbianism together in various configurations" (Abate 2008, xiii-xiv).

Thus, tomboys are complicated characters with multiple forms of sexual preferences. Arya is raised as an independent fighter and is taught to stand on her own feet. Therefore, she rejects classical gender roles because she thinks they make her weak and submissive. Her tomboy identity in a way ensures her survival in dangerous circumstances. Judith Halberstam (1998, 56) argues that:

"Tomboyism generally describes an extended childhood period of female masculinity. (...) Tomboyism is quite common for girls and does not generally give rise to parental fears. Because comparable crossidentification behaviors in boys do often give rise to quite hysterical responses, we tend to believe that female gender deviance is much more tolerated than male gender deviance. Tomboyism tends to be associated with a "natural" desire for the greater freedoms and mobilities enjoyed by boys. Very often it is read as a sign of independence and selfmotivation, and tomboyism may even be encouraged to the extent that it remains comfortably linked to a stable sense of a girl identity".

Arya's profile forms a great contrast with her elder sister Sansa Stark. Sansa is everything Arya is not. She is feminine, beautiful, submissive and always in need of male protection. This is exactly what Arya rejects from the beginning. She deliberately chooses to become an independent person and later to avenge her slaughtered family members. As a tomboy, it is sure that Arya will play a vital role in determining the outcome of events in future episodes of the series.

Moreover, as mentioned before, the characters that make actual differences in Game of Thrones are the non-traditional and non-conformist characters. They are queer, bisexual, butch, tomboy, gay, lesbian, disabled or disadvantaged personalities. They are all figures who do not adhere to heteronormative standards. Another significant category within these non-traditional personalities are the characters which comply with complicit masculinity.

Raewyn Connell $(1995,79)$ formulates complicit masculinity as:

"Masculinities constructed in ways that realize the patriarchal dividend, without the tensions or risks of being the frontline troops of patriarchy, are complicit in this sense. [...] It is the case of a large number of men who have some connection with the hegemonic project but do not embody hegemonic masculinity". 
Characters who comply with complicit masculinity are not as extreme or non-conformist as the subordinate or marginal types of masculinities. They are characters who aspire to become hegemonic but cannot do so due to certain shortcomings or incapabilities.

The first and foremost of these characters is Tyrion Lannister. A dwarf by birth, Tyrion is the youngest son of Tywin Lannister, the head and patriarch of one the wealthiest and most powerful houses of Westeros. Tyrion is one of the major characters of A Game of Thrones and surely deserves special attention. As a dwarf, he is physically disabled but he compensates for his disability through his extraordinary wit and amazing verbal skills. Tyrion is so intellectual and cunning that wherever he goes, he always manages to handle the situation and slip away. He is also a heavy drinker and leads a bohemian life with numerous prostitutes. He has a complex relationship with his father Tywin Lannister, who always favours and openly supports his elder brother Jamie. His father Tywin is a depiction of hegemonic masculinity and is extremely ashamed of having a dwarf as a son. Therefore, he wants to have Tyrion out of the way. Tywin finds the ultimate chance when King Joffrey is killed and Tyrion is accused of murder and finally on trial for the death penalty by none else than his own father. He is suspected of murdering his nephew, King Joffrey of Westeros. In his trial, a dialogue between Tyrion and Tywin reveals their relationship:

"Tywin Lannister: Tyrion, do you wish to confess?

Tyrion Lannister: Yes, father. I'm guilty. Guilty. Is that what you want to hear?

Tywin Lannister: You admit you poisoned the king?

Tyrion Lannister: No. Of that, I'm innocent. I'm guilty of a far more monstrous crime. I'm guilty of being a dwarf.

Tywin Lannister: You are not on trial for being a dwarf.

Tyrion Lannister: Oh, yes I am. I've been on trial for that my entire life.

Tywin Lannister: Have you nothing to say in your defence?

Tyrion Lannister: Nothing but this, I did not do it" (Benioff \& Weiss)

(S.4E.6).

Tyrion's being on trial since his early childhood due to his dwarf body reveals how much he has been suffering throughout his entire life. Tyrion experiences a struggle with his father who does not seem to accept him as a dwarf son, plus an inner struggle to prove himself to the society he lives in. Tyrion finally kills his father with a crossbow and goes on his own quest to fight alongside Khaleesi, Daenerys Targaryen. Tyrion is an example of complicit masculinity mainly due to his being a dwarf, a disability he compensates for, more than any other disabled character. In spite of his short height and little body, he displays qualities that yearn to become hegemonic. He is a sexually active man who has a dominant character and has an incredible gift of strategically analysing situations. Tyrion commands the defence of King's Landing against the fleet of Stannis Baratheon, the so called rightful heir to the throne during the battle of Blackwater. He blows Stannis' entire fleet to smithereens using a mysterious weapon called 'wildfire'. If Tyrion had not been a dwarf, he probably would have been more hegemonic than his father. He is actually a man within a half-man.

Tyrion Lannister is described by Jacoby $(2012,45-46)$ as:

"Able to make their own luck, adapt to new circumstances, and deceive others. They escape numerous life-threatening situations, raise their own armies, and form advantageous alliances. (...) Tyrion spends his time planning the future battle, exploring all the possible courses of action and simulating the fight in his mind. One of Tyrion's greatest strengths is 
his ability to make sudden, radical changes. (...) is capable of exerting mastery over his circumstances in dungeons, in hostile territory, and on the battlefield. Tyrion has only one critical weakness: he is easily distracted by women".

Tyrion's elder brother Jamie Lannister, often referred to as the King slayer, is another example of complicit masculinity. Jamie is his father's favourite son and begins his quest with a perfectly hegemonic masculinity identity, like his father. After being kidnapped, Jamie gets his hand chopped off. Later on, he gets to wear a metal hand in replacement of his own hand and assumes the identity of complicit masculinity. Jamie is now emasculated and become another half-man like his brother Tyrion. He witnesses a deep struggle with this sudden loss of power and later seeks help from Cersei Lannister, his sister whom he has an incestuous relationship. After a long struggle, Jamie ends up in King's Landing, by the side of his secret lover and sister, Cersei Lannister. Like his brother Tyrion, Jamie's emasculation takes place after he loses his hand. This unfortunate event causes him to experience a shift towards complicit masculinity.

Furthermore, Bran Stark is the youngest of Ned Stark's sons. Bran is disabled just like Tyrion. He has a spinal deformation by birth which makes him unable to walk. However, Bran makes up his disability by seeing visions concerning the past and the future. These visions of his prove to be vital as they ensure Bran and his companions' survival from the 'Whitewalker' creatures. His most loyal companion is the massive but disabled character, Hodor. Hodor has a gigantic body but also a serious speech disorder. He has the same single reply to everyone: Hodor. He proves to be a critical asset to Bran's survival as he ultimately sacrifices himself to save Bran’s life.

Finally, Jon Snow is the last of the complicit masculinity characters in Game of Thrones. Unlike the other characters, Jon has no disability or physical shortcoming. He has a different kind of problem. Despite being the son of Ned Stark, former hand to King Robert Baratheon, he has a reputation for being 'the bastard son' of Ned Stark. This terrible reputation haunts him throughout his life. Jon Snow has no other defect but being a bastard and he is constantly being reminded of this very disturbing fact:

\section{"Tyrion Lannister: Let me tell you something, Bastard. Never forget what you are, the rest of the world will not. Wear it like armor and it can never be used to hurt you. \\ Jon Snow: What the hell do you know about being a bastard? \\ Tyrion Lannister: All dwarfs are bastards in their father's eyes" (Benioff \& Weiss) (S.1E.1).}

This conversation reveals a significant, common characteristic between Jon and Tyrion. While Jon possesses a terrible reputation of being a bastard, Tyrion is an awkward dwarf who has been treated as a bastard by his father ever since. Jon is strong, handsome and heterosexual though asexual at first. Jon suffers from loyalty issues due to his reputation as a bastard son. While it is confirmed that his father is Ned Stark, his mother's identity remains unknown. He stands in the shadow of his elder brother, Robb Stark who happens to be a pure Stark. Nevertheless, after the brutal killing of Ned, his wife Catelyn and eldest son Robb Stark, Jon is left alone as the eldest male of house Stark. Jon's is a story of initiation. He begins by joining the Night's Watch, a group of guardians committed to protecting 'the Wall' from the vicious 'White walkers' and rises to the status of 'Lord Commander'. Jon Snow, once the Bastard of Winterfell now becomes the Lord Commander and leader of 'The North'. At the end of the sixth season, Jon Snow has been killed and is later resurrected by a witch. After being resurrected, Jon leads his armies as the Lord Commander of the North (King of the North) and defeats his archenemy, the 
Boltons. It is said that the armies of the North will join forces with the mother of dragons, Daenerys Stormborn Targaryen in order to conquer King's Landing and all of Westeros at the end. Snow exhibits a shift in character, from complicit to hegemonic masculinity. Towards the latter seasons, he becomes a powerful leader with a strong heterosexual identity and a determined leadership. His bastard reputation has now faded away and he is from now on commonly acknowledged as a true Stark.

It is worth noting that the notion of masculinity is not confined to men only. Judith Halberstam points out that female masculinities exist and help us comprehend the construct of masculinities in a better way. (Halberstam 1998, 1) This type of heroic masculine behaviour is manifested by both male and female bodies. (2) Moreover, Judith Butler $(1998,6)$ comments on gender constructs and affirms that:

"The presumption of a binary gender system implicitly retains the belief in a mimetic relation of gender to sex whereby gender mirrors sex or is otherwise restricted by it. When the constructed status of gender is theorized as radically independent of sex, gender itself becomes a free floating artifice, with the consequence that the man and masculine might just as easily signify a female body as a male one, and woman and feminine a male body as easily a female one”.

As expressed by Butler, the notion of gender ought to be free from sex, in order to find its proper equivalent. Once this is achieved, it becomes more convenient to identify that which is signified.

Game of Thrones has a serious dose of female masculinity specifically in two female characters: Daenerys Stormborn Targaryen who goes by the name of 'Khaleesi' and 'the mother of dragons' and Cersei Lannister. Both of these characters are not only antagonist rivals but also nemeses. Daenerys Stormborn Targaryen is the only daughter of ancient King Aerys II Targaryen. The Targaryen dynasty ruled Westeros and Essos for almost three hundred years with a total of thirteen kings. After King Aerys II was overthrown by Robert Baratheon, his two children Viserys and Daenerys were forced into exile. As Daenerys goes into exile, she follows a long and wearisome quest, going from one place to another. She joins the 'Dothraki', a nomadic tribe of warriors that worship horses and by getting raped becomes their queen or so called: 'Khaleesi'. After the death of their Khal, Khaleesi leads the Dothraki on their path. Meanwhile, she also gives birth to three dragons, officially giving her another title: the mother of dragons. In short, Khaleesi goes from city to city and on her way earns herself an army of unsullied soldiers. She conquers the slave city of 'Mereen' and by freeing all the slaves proclaims herself queen of the city.

Khaleesi has one and only goal in life: to reclaim the Iron Throne that belonged to her family for three hundred years. With the help of her dragons, she is willing and prepared to do anything to reach that goal, including eliminating all enemies and slaughtering people if necessary. Therefore, she forms a major threat to King's Landing and the currently reigning Lannister family. Despite her biologically female identity, Daenerys is a fiery case of hypermasculinity. Mosher and Sirkin (1984, 150-163) have defined hypermasculinity as:

"A man's tendency to adhere to a rigid gender role script. The hypermasculine man was theorized to be prepared to challenge any real or imagined provocation from other men with violence. His attitudes toward women were those of sexual or physical subjugation. In short, men who held calloused sexual attitudes, considered violence manly, and 
considered danger exciting were deemed hypermasculine".

Hypermasculine men usually exhibit exaggerated masculine behaviour such as verbally and physically aggressiveness and lower levels of tolerance and empathy. (150-163) Women can also exhibit hypermasculine qualities. Mosher and Sirkin $(1988,61)$ describe these qualities as:

“(a) Callous sexual beliefs, (b) belief that violence is manly, and (c) a view of danger as exciting. Mosher and Tomkins (1988) described the hypermasculine "script" or the rules for the interpretation and manipulation of situations that describe the hypermasculine man's experience".

These authors also assert that hypermasculinity is originated from the machismo ideology which is regarded as a warrior ideology. (64) The warrior has ultimate hegemony over all that he/she conquers and claims total ownership over all subjects. Nothing can stop him/her from reaching his/her true objectives. Hypermasculine characters are ready and fully motivated to take any kind of action in order to accomplish their goals. These actions include violent actions such as slaughtering and all forms of evil schemes.

These are also the exact qualities that describe Khaleesi. She is ultra-dominant, selfish, zerotolerant and powerfully hegemonic. Despite her biological female body, she displays more masculine characteristics than feminine traits. In the first season she uses her sexuality and even risks getting raped in order rise up to the status of queendom and gain control over a group of warriors. After becoming Queen, she openly allowed the humiliating murder of her elder brother and actual heir of the Iron Throne. Daenerys views Viserys as a coward and as someone who is unfit to reign or become a king. She also burns a witch called Mirri Maz Duur alive and kills numerous people on her way to queendom. Khaleesi's intentions seem to be good at first as she wants to become a queen who brings freedom to slaves and sets up laws. However, wherever she goes and whatever city she conquers, she constantly focuses on getting hold of power and postpones her idealist notions of building a free society. She takes famous names such as Jorah Mormont, Daario Noharis, Grey Worm and finally Tyrion Lannister in her service. Khaleesi is good at delivering fiery and epic speeches:

"Daario starts off, but stops when a dragon's roar erupts from the sky. The Dothraki look around. The shadow of a dragon appears on the mountainside. Drogon flies over the Dothraki horde with Daenerys on its back. Drogon circles around and lands in front of the horde. He roars. Daenerys (speaking Dothraki): Every khal who ever lived chose three blood riders to fight beside him and guard his way. But I am not a khal. I will not choose three blood riders. I choose you all.

Daenerys (speaking Dothraki): I will ask more of you than any khal has ever asked of his khalassar! Will you ride the wooden horses across the black salt sea?

Daenerys: Will you kill my enemies in their iron suits and tear down their stone houses?Daenerys: Will you give me the Seven Kingdoms, the gift Khal Drogo promised me before the Mother of Mountains?

Daenerys: Are you with me?

Daenerys: Now and always? Drogon spreads his wings and roars"

(Benioff \& Weiss) (S.6E.6).

Khaleesi's feminine looks and good intentioned first impressions undermine her hypermasculine qualities. Daenerys Targaryen has one and only goal: to seize power by avenging her family and restore the Iron Throne to where it belongs. She is ready to achieve that at any cost and does not 
care about the loss of human lives or the freedom of people. She is the natural nemesis of Cersei Lannister, her antagonist who holds the power in King's Landing. From the beginning of $A$ Game of Thrones, her character experiences a shift from the weak child bride, to the most powerful woman in Westeros. Marrying Khal Drogo grants Daenerys the opportunity she needs to grab power and slowly rise to the rank of empress. After Khal Drogo's death, Daenerys transforms into Khaleesi and gains independence from all male authority. Nevertheless, this shift has a certain cost:

"Of course, none of this power comes without a price. As she gathers her army together, Daenerys begins to sacrifice aspects of her personality. She becomes harder and less compassionate, her choices less personal. A sweetness that she had at the beginning of the series is slowly burning away as she becomes more and more powerful” (Lowder 2012, 142).

Khaleesi's transition into queendom leads to drastic changes in her personality. The tender and sentimental Daenerys is no more. The little, naïve girl is replaced with a powerful, merciless and ambitious queen who is determined to achieve her goals. As soon as she becomes a queen and acquires a large army, she becomes the utmost personification of hypermasculinity; violent and destructive.

Cersei is the daughter of Tywin Lannister and ex-wife and queen of the deceased King Robert Baratheon of Westeros. After Robert's death, their eldest son, Joffrey becomes king and upon his poisoning, his younger brother Tommen ultimately gets to sit on the Iron Throne. Nonetheless, Tommen commits suicide by jumping off from the balcony of his palace, thereby leaving the Iron Throne to none else than Cersei herself. In terms of personality, Cersei is most definitely the cruellest person in A Game of Thrones. She is selfish, cruel, violent, dominant, sly and hypocritical. She possesses hypermasculine traits more than any other character in the series. She is in fact the only character who allows and organizes the rape and torture of another woman. She loses both of her sons but does not grieve, in contrast she sees this as an opportunity to seize power. She has an incestuous relationship with her brother Jamie and despises her younger (dwarf) brother Tyrion. At the end of season six, she takes revenge on everyone that stood in her way by blowing up an entire building full of people using wildfire explosives. Cersei is a character that never hesitates to kill. In a way, she is addicted to power and openly favours violence. Cersei is a ruthless, terrifying killer:

"Cersei Lannister: [to Septa Unella] I drink because it feels good. I killed my husband because it felt good to be rid of him. I fuck my brother because it feels good to feel him inside me. I lie about fucking my brother because it feels good to keep our son safe from hateful hypocrites. I killed your High Sparrow and all his little sparrows, all his septons, all his septas, all his filthy soldiers, because it felt good to watch them burn. Cersei Lannister: [to Septa Unella] This is Ser Gregor Clegane. He's quiet, too. Your gods have forsaken you. This is your god now"

(Benioff \& Weiss) (S.6E.10).

She is the antagonist of Daenerys Targaryen who appears to be a protagonist since the beginning of the series. Either way, both Khaleesi and Cersei are perfect examples of hypermasculinity. Their confrontation is inevitable and enthusiastically expected by many fans and viewers. Though Khaleesi is presented on the good side and Cersei as pure evil, it is actually unclear who is good or evil. In my opinion both characters are evil as both women exhibit typical traits of hypermasculinity. 


\section{Conclusion}

After having analysed the major characters in A Game of Thrones, it can be concluded that the series is based on gender roles and socially constructed identities. As a medieval fantasy, $A$ Game of Thrones bears numerous types of masculinities. In general, the series seems to view women as sexual and submissive objects to have and to hold but towards the latter seasons, there happens serious shifts in gender as women and queer characters take control of all domains. However, these women (Daenerys and Cersei in specific) exhibit characteristics of hypermasculinity. As mentioned earlier, in A Game of Thrones, it is worth noting that the characters that are non-traditional in terms of gender formation are the ones who become determinant in the course of events. The 'non-conformist' characters (queer, bisexual, gay, lesbian, tomboy or butch) play a crucial role in the outcome of the story, whereas the heteronormative characters disappear one by one.

A Game of Thrones is a series that defies and challenges gender roles and shows that people are simply people regardless of their gender or sexual orientation. Despite the fact that A Game of Thrones was harshly criticized in its earlier seasons for being a sexist and discriminative series, it has now proven to have shifted in the opposite direction. The series has become an advocate of non-traditional gender roles, openly exposing all types of queer and non-conformist characters. It could be asserted that the series makes the public question gender issues and more importantly, the series does a wonderful job in raising awareness towards people who do not comply with heteronormative standards. It is almost as if the producers are eager to emphasize that these people exist and deserve the right to live in society as well. From that perspective, Game of Thrones does a fairly good job in gender-bending with these numerous representations of socially constructed gender identities.

Why has A Game of Thrones, a series of books written during the late 1990's, been adapted to television 15 years later in 2011? There exist several answers to this question. An article published on BBC Culture claimed that despite being written 20 years ago, the conditions were not fit for A Game of Thrones to be produced and broadcasted during the late 1990's. (Armstrong 2016) The series' sexual openness and violently disturbing scenes had no place on television during the 1990's. However, in 2011, the conditions were suitable for a daring production like A Game of Thrones to be broadcasted as the company HBO which was already known with defiant series such as Rome and Deadwood. HBO became a safe harbour for $A$ Game of Thrones and despite fierce criticism, the producers' choice proved to be right.

The lack of technological means and special effects was another major reason why the series could not be produced during the 1990's. The series makes tremendous use of state of the art innovations including CGI technology which are imperative in the shooting of fantastic elements and which simply did not exist two decades ago. None of it would have been possible if it had not been for screenwriters David Benioff and D. B. Weiss.

In my opinion, the reason for A Game of Thrones' immense popularity is related to the global rise in authoritarian rule in countries around the world. Often classified within the genre of Medieval-fantasy, the production forms an outstanding example of escapist-fiction. As the series is approaching its final season, it can be observed that the fantastic elements are on the rise over the last seasons. It is not surprising that in times of oppression and authoritarian rule, escapist-fiction, the fantastic in particular, gains tremendous popularity.

Mostly set in pre-industrial times, natural landscapes are beautifully reflected which attract millions of viewers. Beside these, the realistic development of characters and character elaboration are other factors that lie behind the series' popularity. The series does not focus on one single protagonist. A Game of Thrones does not have a hero or heroine but multiple heroes 
and heroines all of whose quests are conveyed in detail. Multiple character development results in multiple stories within the main script. The storyline does not favour any hero/heroine or any particular moral judgment. It is therefore possible for the viewers to associate themselves with the characters or themes presented. There is neither a specific message, nor any kind of judgment.

Moreover, despite being a work of fantastic fiction, A Game of Thrones is completely relevant to our modern-day society as it comprises various details concerning human life. Power relations and struggles between different houses that represent good and evil are perfectly compatible even in our $21^{\text {st }}$ century. Faith, power struggle, family relationships, love, hate, war, slavery, freedom, oppression, segregation, otherness and gender roles are some of the many themes conveyed in this fantasy of the medieval. A Game of Thrones is a pluralist work of fantasy. George Martin's masterpiece is overwhelming in every aspect. In an article about popularizing epic narrative in A Game of Thrones, Ida Rochani Adi (2012, 312) claims that:

"A Game of Thrones is a human product. It is, therefore, not an autonomous area of human experience with significant impact from political, economic and other forms of social behaviour. When a novel becomes best-seller, gains many awards and is made into different forms, it must be because it contains elements that embody values and attitudes that its readers wish to see affirmed. Therefore, the popularity implies some kind of psychological wish fulfilment of the reader".

In terms of masculinity studies, this article makes it clear that as a work of popular culture, $A$ Game of Thrones openly explores and exposes various masculinities to the public around the globe. By presenting numerous models of masculinities through the main characters, the series connects the notion of masculinity with power relations. Since the whole work is about power relations, the destructive nature of masculinity is thereby conveyed through the plot. Right from the beginning, to rise in power, each character, regardless of gender or sexual orientation adheres to specific forms of masculinity. This tragic notion severely criticizes the fact that men, women and queer characters have always needed to conform to different types of masculinity to gain power. This is the case for most of the characters in A Game of Thrones. Cersei, Daenerys, Jon Snow, Rob Stark and many others obviously point out that masculinity leads the way to power, and this in turn to war and destruction. Therefore masculinity is associated with power which is linked to destruction and eventually death.

Moreover, the article also proves that within all types of masculinities, the hegemonic masculinities are the ones that are short lived and meant to be doomed as was stated earlier through characters like Ned Stark, Tywin Lannister, Robert and Stannis Baratheon. All of these characters that openly reflect traits of hegemonic masculinity are tragically and unexpectedly killed whereas the queer and emasculated characters strive and survive through hardships. This covert subversion of gender roles emphasizes that hegemonic masculinity not only kills but also causes self-destruction.

Finally, another emphasis made through Cersei and Daenerys is the very fact that despite being feminine on the outside, both are masculine and hypermasculine on the inside. This case places women inside the circle of masculinity within the scope of power relationships. These women are actually no different than men as they long for and aspire to manifest traits of masculinity. Cersei and Daenerys rule mercilessly as if they are just another king. Their femininity makes no difference, as they merely use their body to achieve their aims. Cersei and Daenerys exploit their followers using hypermasculinity. Thus, women can also be lured into masculinity and this is heavily criticized in A Game of Thrones. 
All in all, it is clear that A Game of Thrones exposes gender and masculinity stereotypes not simply to unveil, but also to subvert and rise against them. A Game of Thrones shows us that masculinity is a threat that has always existed but needs to be eradicated to maintain a peaceful society and way of life. A Game of Thrones not just reveals but also warns us against masculinity's possible outcome which is very likely to end up in sheer catastrophe. In the end, it is not masculinity that will prevail but those who fight to overthrow it in order to establish freedom for each and every human being.

\section{REFERENCES}

Abate M. A. (2008). Tomboys: A literary and cultural history. Philadelphia 2008.

Adi I. R. (2012). "Popularizing epic narrative in George R. R. Martin’s a Game of Thrones”. Humaniora 24 (2012) 303-314. Retrieved from: <https://media.neliti.com/media/publications/11716-IDpopularizing-epic-narrative-in-george-rr-martins-a-game-of-thrones.pdf $>$.

Armstrong J. K. (2016). "Game of Thrones at 20: How the Saga Became a TV Hit". Retrieved from http://www.bbc.com/culture/story/20160419-game-of-thrones-at-20-how-the-saga-became-a-tv-hit

Benioff D. \& Weiss D. B. (Producers). (2011). Game of Thrones [Television series]. US/UK 2011.

Bourdieu P. (2007). Masculine Domination. Cambridge 2007.

Brod H. \& Men’s Studies Association. (1998). Theorizing Masculinities. Thousand Oaks 1998.

Butler J. (1990). Gender Trouble: Feminism and the Subversion of Identity. London 1990.

Connell R. W. \& Messerschmidt J. W. (2005). "Hegemonic Masculinity”. Gender \& Society 19 (2005) 829-859. Doi:10.1177/0891243205278639.

Connell R. W. (1995). Masculinities. Cambridge 1995.

Halberstam J. (1998). Female Masculinities. Durham - London 1998.

Halberstam J. (2013). The Queer Art of Failure. Durham 2013.

Jacoby H. O. (2012). Game of Thrones and Philosophy: Logic Cuts Deeper Than Swords. Hoboken 2012.

Kupers T. (2001). "Psychotherapy with Men in Prison". A New Handbook of Counseling and Psychotherapy Approaches for Men (2001). San Francisco.

Lowder J. (2012). Beyond the Wall: Exploring George R. R. Martin's a Song of Ice and Fire, From a Game of Thrones to a Dance with Dragons. Dallas 2012.

Mares N. M. (2017). "Writing the Rules of Their Own Game”. Ed. B. A. Pavlac, Game of Thrones Versus History: Written in blood (2017) 147-160. Hoboken.

Messerschmidt J. W. (2018). Hegemonic Masculinity: Formulation, Reformulation, and Amplification. Lanham 2018.

Mosher D. L. \& Sirkin M. (1984). "Measuring a Macho Personality Constellation”. Journal of Research in Personality 18 (1984) 150-163. Doi:10.1016/0092-6566(84)90026-6.

Mosher D. L. \& Tomkins S. S. (1988). "Scripting the Macho Man: Hypermasculine Socialization and Enculturation”. Journal of Sex Research 25 (1988) 60-84. Doi:10.1080/00224498809551445.

Spargo T. (2009). Foucault and Queer Theory. Cambridge 2009. 